\title{
EXPLORE
}

\section{Perbandingan Metode Logika Fuzzy Untuk Diagnosa Penyakit Diabetes}

\author{
Hasan Nizar, Alifta Salma Shafira, Juvandio Aufaresa, Muhammad Alvi Awliya, Ummi Athiyah \\ Program Studi Teknik Informatika, Fakultas Informatika \\ Institut Teknologi Telkom Purwokerto \\ Purwokerto, Indonesia \\ 18102088@ittelkom-pwt.ac.id, 18102077@ittelkom-pwt.ac.id,18102235@ittelkom-pwt.ac.id, 18102239@ittelkom- \\ pwt.ac.id, ummi@ittelkom-pwt.ac.id
}

\begin{abstract}
Abstrak- Salah satu faktor yang utama dalam kehidupan manusia yaitu kesehatan. Jika tubuh kita sehat, maka aktivitas harian yang kita lakukan akan berjalan lebih lancar. Namun, tidak dapat dipungkiri tidak sedikit penyakit yang menyebabkan kematian pada manusia. Salah satunya adalah penyakit diabetes. Diabetes merupakan jenis penyakit gangguan metabolik menahun akibat pankreas tidak memproduksi insulin yang cukup atau tubuh tidak dapat menggunakan insulin yang telah diproduksi secara efektif. Penyakit ini masuk ke dalam masalah utama kesehatan masyarakat di Indonesia dan sayangnya tidak dapat disembuhkan, tetapi apabila sudah dideteksi secara dini, segera diterapi, minum obat secara teratur, dan selalu rajin kontrol ke dokter, maka penderita dapat memperbesar tingkat kesembuhannya. Beberapa metode dalam Fuzzy Logic mampu digunakan oleh pakar untuk memprediksi gejala pada diabetes mellitus. Dalam penelitian ini membandingkan tiga metode fuzzy logic dalam mendeteksi dini Diabetes yaitu Meode Fuzzy Mamdani, Metode Fuzzy Sugeno dan Metode Fuzzy Tsukamoto. Metode fuzzy yang digunakan kali ini diharapkan dapat digunakan untuk menentukan tingkat keakurasian untuk mendeteksi penyakit Diabetes. Dari hasil perbandingan diketahui bahwa metode sugeno lebih baik dengan menghasilkan 97,33\% tingkat keakuratan dan nilai eror atau kesalahan yang kecil yaitu kurang dari $3 \%$.
\end{abstract}

Kata Kunci: Diabetes, Fuzzy, Mamdani, Sugeno, Tsukamoto.

\section{Pendahuluan}

Diabetes merupakan penyakit kronis yang berlangsung jangka panjang yang diakibatkan karena meningkatnya kadar gula darah (glukosa) hingga di atas nilai normal. Terdapat 2 jenis utama diabetes, yaitu diabetes tipe 1 dan tipe 2 . diabetes merupakan salah satu penyebab dari kelima besar kematian yang ada di dunia. Lebih dari 3 juta kematian yang diakibatkan oleh penyakit diabetes pada setiap tahunnya. Dapat diartikan bahwa setiap 10 detik 1 nyawa seseorang melayang akibat dari diabetes atau 6 orang dalam setiap menit.[1]

Menurut World Health Organization (WHO) dan National Cholesterol Education Program : Adult Treatment Panel III (NCEP-ATP III), orang yang menderita metabolic syndrome adalah mereka yang mengalami berbagai kelainan, antara lain: tekanan darah tinggi lebih dari 160/90 $\mathrm{mmHg}$, trigliserida darah tinggi lebih dari $160 / 90 \mathrm{mmHg}$, tri gliserida darah lebih dari $150 \mathrm{mg} / \mathrm{dl}$, kolesterol HDL kurang dari $40 \mathrm{mg} / \mathrm{dl}$, obesitas sentral dengan BMI lebih dari 30, lingkar pinggang melebihi $102 \mathrm{~cm}$ pada pria atau $88 \mathrm{~cm}$ pada wanita, atau sudah terdapat mikroalbuminuria.[1]

Penyakit diabetes memiliki dampak yang begitu besar dalam mengurangi tingkat kesehatan dalam masyarakat. Salah satu cara mengurangi dari dampak adanya diabetes adalah dengan mengetahui sebab penyakit diabetes, kemudian dengan mengetahui sebeb tersebut maka kita akan mengurangi dampak yang akan ditimbulkan. Juga perlunya sosialisasi terhadap masyarakat tentang resiko dari penyakit diabetes itu sendiri, sehinga nantinya masyarakat dapat menerapkan hidup sehat dan akan mengurangi resiko dari penyakit diabetes.

Untuk itu perlunya cara pencegahan untuk mengetahui akapah induvidu memiliki resiko dalam penyakit diabetes. Salah satu cara yang dapat dilakukan adalah dengan pendeteksian dini apakah kita berpotensi diabetes atau tidak, sehingga nantinya hasil tersebut dapat menjadi pertimbangan untuk induvidu dalam mejaga pola hidup sehat. Juga sebagai pendeteksi pasien diabetes yang belum terdeteksi sehingga nantinya dapat ditangani dengan lebih cepat sebagai pencegahan adanya komplikasi yang lebih lanjut.

Banyak metode yang dapat digunakan salah satu contohnya Fuzzy. Furzy Logic adalah metode sistem pendukung keputusan yang cocok untuk diimplementasikan pada pemilihan tipe diabetes. Furay logic merupakan sistem yang dapat menghitung dan memutuskan dengan baik. Furzy Logic atau Logika Furzy merupakan salah satu metode untuk menentukan sebuah 
keputusan. Logika klasik menyatakan bahwa segala hal dapat dinyatakan dengan pilihan 0 atau 1, hitam atau putih serta ya atau tidak, logika Fuz:y menggantikan pilihan tersebut dengan tingkat kebenaran yang berbeda. [2] Tujuan dari penelitian adalah untuk membandingkan hasil dari 3 macam metode Furzy yaitu Mamdani, Sugeno, Tsukamoto dalam medeteksi penyakit diabetes. Sehingga kita dapat mementukan metode Fuz:y mana yang

\section{Metodologi}

Penelitian ini menggunakan metode jurnal review yang bertujuan untuk membandingkan metode fur:y terbaik dalam penerapannya untuk diagnosa penyakit Diabetes. Dalam penelitian ini kami membandingkan 3 metode fuzzy yaitu Mamdani, Sugeno, Tsukamoto. Tahap pertama

\section{Hasil dan Pembahasan}

\section{A. Metode Fuzzy Mamdani}

Metode furay mamdani sering juga dikenal dengan nama metode min-max. Dimana menggunakan min atau minimal pada fungsi implikasi dan max atau maksimuk pada komposisi antar fungsi implikasi. Dalam penerapannya metode furay madani menggunakan 4 tapan yaitu pembentukan himpunan fuzzy, aplikasi fungsi implikasi, komposisi aturan, defuzzifikasi. Pada metode furay mamdani ini baik variabel input atau masukannmaupun dari variabel output atau keluaran berbentuk himpunan baik menjadi satu atau banyak. Metode Fur:y Mamdani merupakan salah satu bagian dari Fuz:y Inference System yang berguna untuk penarikan kesimpulan atau suatu keputusan terbaik dalam permasalahan yang tidak pasti (Bova, 2010). Metode Furzy Mamdani diperkenalkan secara umum oleh Ebrahim Mamdani pada tahun 1975.[8]

Dalam jurnal yang ditulis oleh Munawar, Marzuki, Radhiah dengan menggunakan 3 variabel masukan (input) yaitu usia, tekanan darah, dan kolesterol serta variabel keluaran (output) yaitu resiko penyakit diabetes. Dengan data sampel sebanyak 20 buah yang berasal dari Rumah Sakit Umum Daerah Zainoel Abidin Banda Aceh. Proses untuk klasifikasi resiko terkena penyakit Diabetes yaitu dengan penentuan variabel masukan, penentuan sistem inferensi furzy mamdani, kemudian yang terakhir penerapan dari aturan dengan toolbox FIS Matlab. Perancangan sistem inferensi fuz:y (FIS) yang dibuat dengan menggunakan gabungan fungsi keanggotaan yaitu segitiga dan trapesium. Kesimpulan yang dapat dihasilkan dari penelitian ini adalah semakin tua usia seseorang dengan kolestrol yang tinggi maka akan semakin besar peluang seseorang terkena penyait Diabetes. Pada penelitian ini metode furzy mamdani adalah salah satu metode yang terbukti memiliki keakuratan yang tinggi karena kompleksnya perhitungan yang ditemukan didalamnya.[4]

Penelitian oleh Slamet Riyadhi dengan menggunakan variabel masukan (input) dan keluaran (output) yaitu umur, berat badan, tekanan darah, resiko diabetes. Dalam menghasikan keputusan terbaik dengan resiko yang kecil. Dengan mengetahui bahwa suatu metode mempunyai keputusan yang terbaik dari metode lainnya tentunya akan menghasilkan efisiensi dalam mendeteksi penyakit diabetes, serta nantinya akan digunakan dalam sistem pendeteksi penyakit diabetes dan memudahkan pasien dalam mendiagnosis penyakit ini.

yang dilakukan adalah mencari dan menentukan jurnal terkait dengan diagnosa penyakit Diabetes. Tahap selanjutnya adalah merangkum isi dari setiap komponen jurnal untuk menentukan beberapa kelebihan dan kekurangan setiap metode yang diterapkan.

penelitian ini digunakan data sekunder dari Rumah Sakit Umum Daerah Dr.H. Soemarno Sostroatmojo Kuala Kapuas yang berupa sampel data pasian yang positif dan tidak positif sebagai penderita penyakit diabetes. Penelitian ini melakukan perbandingan hasil yang telah dihitung dengan menggunakan metode fuzzy mamdani dan data sampel milik pasien yang ada di Rumah Sakit Umum Daerah Dr.H. Soemarno Sostroatmojo Kuala Kapuas. Penelitian ini menghasilkan data sebagai berikut : dari jumlah sampel yang digunakan sebanyak 120 sampel data pasien, metode furzy mamdani memiliki hasil 102 sampel data pasien yang akuransinya benar dan hanya sebesar 18 sampel data pasien yang meleset dari hasil sesungguhnya. Sehingga dapat dihitung berapa persen tingkat akurasi metode Mamdani untuk deteksi diabetes dengan persamaan: \% Akurasi = (Jumlah Data Akurat / Total Sampel $) \times 100=(102 / 120) \times 100=85 \%$ dan kesalahan $15 \%$. Dalam menganalisis diabetes ini sistem inferensi metode Mamdani, semakin banyak variabel yang digunakan sebagai inputan maka tingkat ketelitian dalam melakukan analisis data semakin tinggi.[5]

Penelitian oleh Jimmy Singla dengan menggunakan 8 variabel yaitu polydispia, polyuria, polyhagia, berat badan (weight loss), tingkat kelelahan (tiredness), ketajaman penglihatan (blurred vision), sakit kepala (dizziness) serta menggunakan 150 sampel data pasien yang telah terdiagnosis sebelumnya. Pada penelitian ini membandingkan hasil yang telah ada dengan hasil menggunakan metode furzy. Hasil penelitian yaitu dari 150 kasus pasien yang terdiagnosis, pada kolom pertama terdapat 40 kasus pasien yang telah terdiagnosis dikategorikan sebagai diabetes tipe 1 dimana 36 pasien terdiagnosis masuk kategori dapat diterima dan 4 pasien terdiagnosis salah dikategorikan. Kolom kedua menunjukkan, dari total 35 kasus pasien yang terdiagnosis, 32 pasien dikategorikan sebagai penderita diabetes tipe 2 dan 3 kasus pasien terdiagnosis salah dikategorikan. Kolom ketiga menunjukkan, dari 40 kasus pasien yang terdiagnosis, semuanya 40 dikategorikan pradiabetes dan tidak ada kasus pasien yang salah dikategorikan. Selain itu pada kolom keempat terlihat, 
dari total 35 kasus pasien yang terdiagnosis, seluruh 35 pasien dikategorikan bebas diabetes dan tidak ada kasus pasien yang salah kategorikan. Secara umum, Dari 150 kasus pasien terdiagnosis 143 kasus pasien terdiagnosis masuk kategori dapat diterima dan 7 kasus pasien terdiagnosis masuk kategori salah. Hasil penelitian menunjukkan penilaian yang dicapai oleh sistem inferensi furay tipe mamdani dapat diterima untuk kasus pasien 143 yaitu 95,33\% dan kasus pasien salah diagnosis - 7 yaitu $4,67 \%$ [7]

\section{B. Metode Fuzzy Sugeno}

Model Furzy Sugeno ( model furzy TSK) diajukan oleh Takagi, Sugeno, dan Kang ( Takagi dan Sugeno, 1985) dalam upaya untuk membangun pendekatan sistematis untuk membangkitkan aturan -aturan fuzzy dari himpunan data input - output yang diberikan. Suatu aturan furzy khas dalam model furzy Sugeno dibentuk: if $x$ is $A$ and $y$ is $B$ then $z=f(x, y)$, dimana $A$ dan $B$ himpunan furzy dalam anteseden dan $z=f(x, y)$ fungsi tegas dalam konsekuen. Jika $\mathrm{f}(\mathrm{x}, \mathrm{y})$ polimonial orde satu, FIS yang dihasilkan disebut model fuzzy Sugeno orde satu. Jika f konstan, dihasilkan model fuzzy Sugeno orde nol. Sistem inferensi fur:y menggunakan metode Sugeno memiliki beberapa karakteristik, yaitu konsekuen tidak merupakan himpunan furzy, namun merupakan suatu persamaan linear dengan variabel - variabel sesuai dengan variabel - variabel inputnya.[9]

Penelitian oleh Rahmat Tulllah, Siti Maisaroh Mustafa, Abdul Rochim yaitu mendeteksi penyakit diabetes dengan menggunakan metode furzy logic Sugeno dengan menggunakan 3 variabel masukan (input) yaitu Gula Darah Puasa (GDA), Gula Darah 2 jam PP (GDPP), kadar HbA1c. Dengan menggunakan data sampel yang diambil dari Klinik pratama yang berdiri dibawah naungan CV. Empat Saudara Jaya yang terletak di Jl.M. Siban Rt 03/ Rw 014 Kel. Kunciran Indah, Kec. Pinang Tangerang - Banten. Metode Furzy Logic Sugeno mampu membantu pengguna untuk mendiagnosa penyakit diabetes(DM) dengan Tahap pengaburan (fuzzification) yakni pemetaan dari masukan tegas ke himpunan kabur, tahap inferensi, yakni pembangkitan aturan kabur, tahap penegasan (defuzzification), yakni tranformasi keluaran dari nilai kabur kepada nilai tegas. Kesimpulan yang dihasilkan dari penelitian ini adalah metode fuzay Sugeno mampu mendeteksi penyakit diabetes dengan baik dan dapat bermanfaat bagi pasien, dokter, maupun tenaga medis.[6]

Pada penelitian yang sama dengan menggunakan metode mamdani diatas oleh Jimmy Singla dengan menggunakan 8 variabel yaitu polydispia, polyuria, polyhagia, berat badan (weight loss), tingkat kelelahan (tiredness), ketajaman penglihatan (blurred vision), sakit kepala (dizziness) serta menggunakan 150 sampel data pasien yang telah terdiagnosis sebelumnya. Pada penelitian ini membandingkan hasil yang telah ada dengan hasil menggunakan metode furzy. Hasil penelitian ini yaitu dengan total 150 kasus pasien yang terdiagnosis, pada kolom pertama terdapat 40 kasus pasien yang terdiagnosis dikategorikan sebagai diabetes tipe 1 dimana 38 pasien terdiagnosis masuk kategori dapat diterima dan 2 pasien terdiagnosis salah dikategorikan. Kolom kedua menunjukkan, dari total 35 kasus pasien yang terdiagnosis, 33 kasus dikategorikan sebagai diabetes tipe 2 dan 2 kasus pasien yang terdiagnosis salah dikategorikan. Kolom ketiga menunjukkan, dari total 40 kasus pasien yang sudah terdiagnosis ke- 40 kasus tersebut dikategorikan pradiabetes dan tidak ada satupun kasus pasien yang salah dikategorikan. Selain itu pada kolom keempat terlihat, dari total 35 kasus pasien yang terdiagnosis, seluruh 35 pasien dikategorikan bebas diabetes dan tidak ada kasus pasien yang salah kategorikan. Secara umum, dari 150 kasus pasien terdiagnosis 146 kasus pasien terdiagnosis masuk kategori dapat diterima dan 4 kasus pasien terdiagnosis ternyata salah dikategorikan. Hasil penelitian menunjukkan penilaian yang dicapai oleh sistem inferensi fuzzy tipe sugeno dapat diterima untuk kasus pasien - 146 yaitu sebesar $97,33 \%$ dan kasus pasien salah diagnosis - 4 yaitu $2,67 \% \cdot[7]$

\section{Metode Fuzzy Tsukamoto}

Metode logika fur:y Tsukamoto untuk setiap konsekuen pada aturan yang berbentuk IF-Then harus direprentasikan dengan suatu himpunan fuzzy dengan fungsi keanggotan yang monoton, sehingga rule tersebut sesuai dengan keadaan yang menjadi masalah. Keluaran dari metode Tsukamoto hasil inteferensi dari tiap-tiap aturan diberikan secara tegas (crisp) berdasarkan $\alpha$ predikat (fire strength). Hasil yang akan diperoleh dengan menggunakan rata-rata berbobot dari semua data.[8]

Penelitian Oleh Heny Yuniarti, Riyanto Sigit, dan Muhammad Aunur Rofiq untuk mengetahui tingkat keakuratan tiap sensor, hasil dari tiap sensor selanjutnya dibandingkan dengan alat medis yang sudah teruji, atau alat yang sering digunakan dokter untuk melakukan pengecekan, sehingga alat-alat medis tresebut dapat mendeteksi penyakit seperti hipoksemia, hipotermia, hipertensi, diabetes dengan baik. Dengan sampel 20 data untuk masing-masing sensor menggunakan fur:y tsukamoto dalam perhitungan secara manual sehingga nantinya dibandingkan dengan sistem. Pada data pengujian sensor suhu tubuh

dengan alat medis, pengujian sudah dilakukan sebanyak 12 kali dan mendapatkan rata-rata error sebanyak 1,05\%. Pada sensor SPO2 menghasilkan 2 keluaran yaitu keluaran SPO2 dan juga keluaran detak jantung. Pertama yaitu keluaran SPO2 dilakukan pengujian sebanyak 20 kali dan menghasilkan rata-rata error sebesar 1,90\%. Kedua yaitu keluaran detak jantung melakukan sebanyak 20 kali dan mendapatkan hasil rata - rata error sebanyak 5,78\%. Sensor tekanan darah memiliki 2 keluaran yaitu tekanan darah sistolik dan tekanan darah diastolik. Untuk keluaran tekanan darah sistolik dilakukan sebanyak 15 kali dan memiliki rata - rata error sebanyak 4,16\%. Pengujian untuk keluaran dari tekanan darah diastolik memiliki rata - rata error sebanyak 4,87\% dan pengujian dilakukan sebanyak 15 kali. Membandingkan keluaran sensor gula darah dilakukan sebanyak 15 kali dan hasilnya mendapatkan rata - rata error sebesar 4,01\%. Pengujian dilakukan sama seperti pengujian klasifikasi penyakit hipoksemia, hipertensi, hipotermia, diabetes. Hasil pengujian dalam mendeteksi penyakit diatas adalah 
akurasi data sensor dan perhitungan secara manual fuгzy hasilnya sama.[3]

Penelitian oleh Rico Adrial, Vitriani, Sri Rahayu Alfitri Usna untuk menganalisis dan membandingkan hasil keputusan tipe diabetes menggunakan metode Mamdani dan Tsukamoto serta untuk menguji hasil kalkulasi dengan furzy logic kedua metode tersebut dengan hasil keputusan yang sebenarnya terjadi pada kasus penentuan tipe diabetes melitus Furzy Mamdani, Furzy Tsukamoto.
Penggunaan furzy logic menggunakan metode Mamdani lebih optimal dalam kasus penentuan tipe diabetes dibandingkan dengan menggunakan metode Tsukamoto. Hasil dari kalkulasi manual menunjukan bahwa metode Mamdani lebih mendekati dengan hasil dari keadaan yang sebenarnya. Walaupun proses kalkulasi metode Mamdani membutuhkan waktu yang lebih lama, tetapi hasil yang diberikan ternyata lebih tepat [2].

Tabel 1 Perbandingan 3 Metode Fuqzy (Mamdani, Sugeno, Tsukamoto)

\begin{tabular}{llll}
\hline \multicolumn{1}{c}{ Indikator } & \multicolumn{1}{c}{ Mamdani } & \multicolumn{1}{c}{ Sugeno } & \multicolumn{1}{c}{ Tsukamoto } \\
\hline Keakuratan & Metode mamdani & Metode sugeno & Metode tsukamoto belum ada nilai secara \\
dalam & memperoleh hasil $80 \%$ & memperoleh hasil & utuh keakuratan dalam analisis namun \\
menganalisa & hingga $\pm 95 \%$, dalam & $>95 \%$ dalam & dalam penelitian ini jika dibandingkan \\
& penelitian ini hasil & penelitian ini tertinggi & dengan metode mamdani keakuratannya \\
& tertinggi adalah 95,33\% & dengan nilai $97,33 \%$ & lebih kecil.
\end{tabular}

\begin{abstract}
Kesalahan dalam Nilai kesalahan yaitu menganalisa $\quad<5 \%$, dalam penelitian ini tertinggi 4,67\%
\end{abstract}

\author{
Kesalahan dalam \\ analisis adalah $<3 \%$ \\ dalam penelitian ini \\ yang tertinggi $2,67 \%$
}

Rata-rata eror $<6 \%$, dalam penelitian ini nilai eror terbesar adalah $5,78 \%$

Proses kalkulasi manual metode tsukamoto membutuhkan waktu yang lebih sedikit dari metode mamdani. metode mamdani membutuhkan waktu yang lama.

Perhitungan

Perhitungan dari metode ini terbilang rumit.

Proses kalkulasi manual metode sugeno membutuhkan waktu tidak terlalu lama, jika dibandingkan dengan mamdani.

Perhitungan dari metode ini terbilang cukup rumit.
Perhitungan dari metode ini terbilang paling sederhana dari metode mamdani maupun sugeno.

\section{Kesimpulan}

Disimpulkan dari data penelitian dari beberapa jurnal didapatkan bahwa metode terbaik dalam mendiagnosa penyakit diabetes adalah Metode Fuzzy Sugeno. Alasan yang pertama yaitu nilai keakuratan yang lebih tinggi dari ke 2 metode yang lain yaitu 97,33\%, nilai eror atau kesalahan yang kecil yaitu kurang dari 3\%, perhitungan manual yang tidak terlalu memakan waktu, dan perhitungan yang sedang dalam artian tidak begitu rumit. Mungkin dalam hitungan dapat dibilang sedikit rumit namun dengan banyak keunggulan dari ke 3 metode yang dibandingkan.

\section{Ucapan Terima Kasih}

Ucapan terima kasih kepada pihak yang telah berperan dalam penyusunan jurnal yang berjudul "Perbandingan Metode Logika Furzy untuk Diagnosa Penyakit diabetes", hingga akhirnya jurnal review ini dapat selesai.

\section{Daftar Pustaka}

[1] T. Hans, "Segala Sesuatu yang Harus Anda Ketahui Tentang Diabetes," Jakarta : PT Gramedia Pustaka, 2008.

[2] A. Rico., Vitriani., U. S. Rahayu Alfitri "Analisis Perbandingan Kalkulasi Manual Fuгzy Logic Metode Mamdani Dan Tsukamoto Pada Penentuan Tipe Diabetes Melitus," Journal of Education Informatic Technology and Science (JeITS) ., vol. 2, no 3, pp.1223, 2020

[3] Yuniarti, Heny, S. Riyanto, R. M. Aunur, "Penerapan Fuzzy Tsukamoto pada Alat Deteksi Penyakit Hipoksemia, Hipotermia, Hipertensi, dan Diabetes untuk Health Care Kiosk," Journal of Applied Informatics and Computing (JAIC)., vol.4, no.2, pp.163-173,2020.

[4] Munawar, Marzuki, Radhiah, "Pendeteksian Penyakit Diabetes di RSUD Zainoel Abidin Banda Aceh dengan Sistem Fuzzy Mamdani," Journal of Data Analysis., vol. 1, no. 2, pp. 103-110,2018. 
[5] R. Slamet, "Uji Coba Metode Mamdani untuk Deteksi Penyakit Diabetes Di Rsud Dr. H. Soemarno Sosroatmojo Kuala Kapuas," Jurnal INTEKNA : Informasi Teknik dan Niaga Politeknik Negeri Banjarmasin., vol. 13, no. 1, pp. 70-77,2013.

[6] T. Rahmat, Mustafa, S. Maisaroh, R. Abdul, "Sistem Pakar Pendeteksi Penyakit DiabetesMenggunakan Algoritma Fuzzy Logic Takagi Sugeno Kang," Jurnal Sisfotek Global Stmik Bina Sarana Global., vol. 9, no. 2, pp. 98-105,2019.

[7] Singla, Jimmy, "Comparative Study of Mamdani-Type and Sugeno-Type Fuzzy Inference Systems for Diagnosis of Diabetes," International Conference on Advances in Computer Engineering and Applications
(ICACEA) IMS Engineering College., Ghaziabad, India. 2015.

[8] Yulmaini, "Logika Fuzzy: Studi Kasus \& Penyelesaian Menggunakan Microsoft Excel dan Matlab," Yogyakarta: Penerbit Andi., 2018.

[9] S. S. Lina Mulani, "Penerapan Fuzzy Inference System Sugeno untuk Menentukan Jumlah Pembelian Obat (Studi Kasus: Garuda Sentra Medika)," Jurnal Informatika Universitas Pamulang., vol. 3, no.2, pp. 104-109, 2018

[10] Adrial, Rico, "Fuzzy Logic Modeling Metode Sugeno Pada Penentuan Tipe Diabetes Melitus Menggunakan MATLAB,'Jurnal Ilmiah Informatika., vol. 6, no. 1, pp. 62-68,2018. 